\title{
Synthesis and Physicochemical Studies of Some 2-substituted-1-phenyl-1,3-butanedionato Nickel(II) and Copper(II) Complexes And Their 2,2'-Bipyridine and 1,10-Phenanthroline Adducts
}

\author{
Oluwatola Omoregie (Corresponding author) \\ Department of Chemistry, Faculty of Science, University of Ibadan \\ Ibadan, Oyo-State, Nigeria \\ E-mail: tolaomoregie@yahoo.co.uk \\ Joseph Woods \\ Department of Chemistry, Faculty of Science, University of Ibadan \\ Ibadan, Oyo-State, Nigeria \\ E-mail: jaowoods@yahoo.com
}

The authors are grateful to Third World Organization for Women in Science and Department of Chemistry University of Ibadan, Nigeria for the fellowship awarded and the provision of chemicals and solvents respectively.

\begin{abstract}
The nickel(II) and copper(II) complexes of 2-substituted-1-phenyl-1,3-butanedione (2-R-bzacH, $\mathrm{R}=\mathrm{Cl}, \mathrm{NO}_{2}$ ) and their 2,2'-bipyridine (bipy) and 1,10-phenanthroline (phen) adducts have been synthesized and characterized by microanalysis, conductance, magnetic and spectral measurements. The conductivity measurements in nitromethane indicate that the complexes are non-electrolytes while all the adducts are electrolytes except $\mathrm{Ni}\left(\mathrm{NO}_{2} \text {-bzac }\right)_{2}$ bipy and $\mathrm{Cu}\left(\mathrm{NO}_{2} \text {-bzac) }\right)_{2}$ phen which are non-electrolytes. The room temperature magnetic moments suggest that the $\mathrm{Cu}\left(\mathrm{NO}_{2} \text {-bzac }\right)_{2}$ is a dimer while the visible absorption spectra of the compounds suggest plausible 4-, 5- and 6-coordinate geometry for these compounds. The infrared spectra of the complexes showed that lower frequency shifts of varying magnitudes were observed in the carbonyl stretching frequencies on complexation.
\end{abstract}

Keywords: 2-substituted-1-phenyl-1,3-butanedione, Spectra studies, Magnetic moments, Conductance measurement

\section{Introduction}

A survey of the literature reveals that metal $\beta$-diketonates have found use as fuel additives, trace metal analysis by gas chromatography and numerous other extraction applications (Wenzel et al, 1985). The dissolution of chelating agents in supercritical fluids has been explored as a possible route to waste cleanup (Laintd et al, 1992; Lalntz et al, 1994; Wang et al, 1995; Wang et al, 1994). Complexes of $\beta$-diketones are reported to have potentially useful pharmacological properties (Onawumi et al, 2008).

Literature is available on the introduction of halogens and nitronium ion at the central carbon atom of $\beta$-diketones $\left[\left(\mathrm{R}_{1} \mathrm{COCH}_{2} \mathrm{COR}_{2}\right)\right.$ where $\left.\mathrm{R}_{1}=\mathrm{R}_{2}=\mathrm{CH}_{3}\right]($ Singh and Sahai, 1967a; Singh and Sahai, 1967b; Woods and Patel,1994; Patel and Woods, 1990a; Collman et al, 1962; Ebeid et al, 1966; Tanaka et al, 1969 ) whereas little work has been carried out on the synthesis and characterization of the nickel(II) and copper(II) complexes of 2-substituted-1-phenyl-1,3-butanedione (2-R-bzacH, $\left.\mathrm{R}=\mathrm{Cl}, \mathrm{NO}_{2}\right)$ and their 2,2'-bipyridine (bipy) and 1,10-phenanthroline (phen) adducts. In continuation of our work on substituted $\beta$-diketones (Woods et al, 2009a; Woods et al, 2009b), we report the results of our investigations on the nickel(II) and copper(II) complexes of some 2-substituted-1-phenyl-1,3-butanediones (2-R-bzacH, $\mathrm{R}=\mathrm{Cl}, \mathrm{NO}_{2}$ ) and their adducts with 2,2'-bipyridine (bipy) and 1,10-phenanthroline (phen).

\section{Experimental}

The following reagents were used: 1-phenyl-1,3-butanedione or benzoylacetone (bzacH) (Aldrich chemicals), sulphuryl chloride, copper nitrate, nickel acetate, copper acetate, 2,2'-bipyridine and 1,10-phenanthroline (analytical grade). 


\subsection{Synthesis of the Ligands}

The ligands, 2-chloro-1-phenyl-1,3-butanedione (Tanaka et al, 1969) and 2-nitro-1-phenyl-1,3-butanedione (Singh and Sahai, 1967a) were prepared by literature methods.

\subsection{Synthesis of the Complexes and Adducts}

\subsubsection{Synthesis of $\mathrm{Cu}(\mathrm{Cl}-\mathrm{bzac})_{2}$}

Cl-bzacH (2.00 mL, 12.4 mmoles) in $6 \mathrm{~mL}$ acetone was added to copper(II) acetate monohy drate $(1.24 \mathrm{~g}, 6.2$ mmoles) in $50 \mathrm{~mL} 60 \%$ methanol in drops. The mixture was stirred for 1 hour and the precipitates formed were filtered, washed with $60 \%$ methanol and dried in the vacuo. All the other complexes were prepared using similar procedure.

\subsubsection{Synthesis of $\mathrm{Cu}(\mathrm{Cl}-\mathrm{bzac})_{2}$ phen}

The phenanthroline adduct of $\mathrm{Cu}(\mathrm{Cl} \text {-bzac })_{2}$ was prepared by adding the solid complex $(0.50 \mathrm{~g}, 1.1 \mathrm{mmol})$ while stirring to phenanthroline $(0.72 \mathrm{~g}, 3.6 \mathrm{mmol})$ dissolved in $10 \mathrm{~mL}$ hot chloroform solution. The mixture was further stirred for 15 minutes and the precipitates formed were filtered and washed with acetone. This was dried in vacuo over anhydrous calcium chloride. Other adducts were prepared using similar procedures.

\subsection{Physical measurements}

Elemental analyses for $\mathrm{C}, \mathrm{H}, \mathrm{N}$ were determined at Department of Chemistry, Loughborough University, UK. The $\%$ metal in the nickel(II) and copper(II) compounds were determined titrimetrically using EDTA.

The molar conductivities of the soluble compounds in nitromethane at room temperature were determined using Digital conductivity meter (Labtech).

The solution spectra of the the Ligands, nickel(II) and copper(II) compounds in methanol and chloroform were recorded on a Unicam UV-Visible Spectrophotometer using $1 \mathrm{~cm}$ glass cell. The reflectance spectra of the Ligands, nickel(II) and copper(II) compounds were recorded on a Perkin Elmer Lambda 950 UV/VIS spectrophotometer at the Department of Chemical Engineering, Faculty of Technology, Addis Ababa University, Ethiopia using calcium carbonate as reference. The infrared spectra of the compounds as pressed $\mathrm{KBr}$ disc were recorded on Perkin Elmer Spectrophotometer BX FT-IR.

\section{Results and discussion}

Table I shows the analytical data, colours, \%yield and room temperature magnetic moments $\left(\mu_{\text {eff }}\right)$ of the prepared nickel(II) and copper(II) compounds. The elemental analyses were in good agreement with those calculated for the proposed formula (Table 2). The nickel(II) compounds prepared from 2-chloro-1-phenyl-1,3-butanedione were generally pink in colour except $\mathrm{Ni}(\mathrm{Cl} \text {-bzac })_{2} \cdot 2 \mathrm{H}_{2} \mathrm{O}$ which had green colour while those prepared from 2- $\mathrm{NO}_{2}$-1-phenyl-1,3-butanedione were obtained as various shades of green except $\left[\mathrm{Ni}\left(\mathrm{NO}_{2}\right.\right.$-bzac $\left.)(\mathrm{phen})_{2}\right]\left(\mathrm{NO}_{2}\right.$-bzac) which was obtained as Light brown. All the copper(II) complexes and their adducts were obtained as varous shades of green colour.

The magnetic moment data as shown in Table 1 depicts the paramagnetic nature of the compounds. The nickel(II) compounds had values in the range 2.9-3.28 B.M. which is in agreement with the range expected for octahedral nickel(II) complexes (2.9-3.3 B.M) (Patel and Woods, 1990b). A moment of 1.73-2.2 B.M. is usually observed for magnetically dilute copper(II) compounds, with compounds whose geometry approaches octahedral having moments at the lower end while those approaching tetrahedral geometry are at the higher end (Patel and Woods, 1990c). The prepared 2-substituted-1-phenyl-1,3-butanedionato copper(II) compounds had moments in the range 1.44-2.19 B.M. The magnetic moment of $\mathrm{Cu}\left(\mathrm{NO}_{2} \text {-bzac }\right)_{2}$ (1.44 B.M.) is lower than the spin only value of 1.73 B.M. which is indicative of dimerization with the possibility of $\mathrm{Cu}-\mathrm{Cu}$ linkage (Cotton and Wilkinson, 1988).

The molar conductivity of the complexes in nitromethane were in the range $17-21 \mathrm{ohm}^{-1} \mathrm{~cm}^{2} \mathrm{~mol}^{-1}$ indicating that they are non-electrolytes. The adducts had values between $62-198 \mathrm{ohm}^{-1} \mathrm{~cm}^{2} \mathrm{~mol}^{-1}$ except $\mathrm{Ni}\left(\mathrm{NO}_{2} \text {-bzac }\right)_{2}$ bipy and $\mathrm{Cu}\left(\mathrm{NO}_{2} \text {-bzac }\right)_{2}$ phen which are non-electrolytes (13 and $46 \mathrm{ohm}^{-1} \mathrm{~cm}^{2} \mathrm{~mol}^{-1}$ respectively).

The principal IR absorption bands of the prepared complexes are listed in Table 3. In the spectrum of $\mathrm{NO}_{2}-\mathrm{bzacH}$, the band at $1600 \mathrm{~cm}^{-1}$ has been assigned as $v_{\mathrm{as}}(\mathrm{C}=\mathrm{O})+v_{\mathrm{as}}(\mathrm{C}=\mathrm{C})+v_{\mathrm{as}}\left(\mathrm{NO}_{2}\right)$ vibrations while those at $1360 \mathrm{~cm}^{-1}$ and $820 \mathrm{~cm}^{-1}$ are assigned as $v_{\mathrm{s}}\left(\mathrm{NO}_{2}\right)$ and $v(\mathrm{C}-\mathrm{N})$ or $\delta \mathrm{N}-\mathrm{O}$ respectively. Bathochromic shifts of varying magnitude were observed in the asymmetric $\mathrm{C}-\mathrm{O}$ and $\mathrm{C}-\mathrm{C}$ stretching vibrations of the complexes relative to their respective ligands whereas hypsochromic shifts were observed in all the adducts relative to the complexes. Multiple bands of $v_{\mathrm{s}}(\mathrm{C}-\mathrm{O})+\delta \mathrm{C}-\mathrm{H}$ were observed in all the compounds except $\left[\mathrm{Ni}(\mathrm{Cl}-\mathrm{bzac})(\mathrm{bipy})\left(\mathrm{H}_{2} \mathrm{O}\right)_{2}\right](\mathrm{Cl}-\mathrm{bzac})$, $\left[\mathrm{Ni}(\text { phen })_{2}\left(\mathrm{H}_{2} \mathrm{O}\right)_{2}\right](\mathrm{Cl}$-bzac $)$ and $\left[\mathrm{Ni}(\mathrm{Cl}-\right.$ bzac $)($ phen $\left.)\left(\mathrm{H}_{2} \mathrm{O}\right)_{2}\right](\mathrm{Cl}-$ bzac $)$ which had single band. Studies have shown 
that methyl deformation band occurred at around $1425 \mathrm{~cm}^{-1}$ in acetylacetone (Holtzclaw and Collman, 1957; Belford et al, 1956) while bands in the $1420-1350 \mathrm{~cm}^{-1}$ region have been assigned as $\delta_{\mathrm{as}}\left(\mathrm{CH}_{3}\right)+\delta_{\mathrm{s}}\left(\mathrm{CH}_{3}\right)$ vibrations (Singh and Sahai, 1967b; Tanaka et al, 1969; Patel and Woods, 1990b; Koshimura et al, 1973; Nakamoto et al, 1961). Furthermore, the $v \mathrm{M}-\mathrm{O}+v \mathrm{C}-\mathrm{N}$ vibrational modes occurred below $700 \mathrm{~cm}^{-1}$ (Patel and Woods, 1990a; Patel and Woods, 1990c). The C-H deformation bands $(\delta \mathrm{C}-\mathrm{H})$ for the bipyridine appeared at around $768 \mathrm{~cm}^{-1}$ while that of the phenanthroline adducts were observed at $852 \mathrm{~cm}^{-1}$ and $727 \mathrm{~cm}^{-1}$.

The electronic spectra of the ligands in $\mathrm{CHCl}_{3}$ and methanol are listed in Table 4. Single bands of the $\pi_{3}-\pi_{4}{ }^{*}$ were observed in the $31,250-31,154 \mathrm{~cm}^{-1}$ region in Cl-bzacH and $\mathrm{NO}_{2}$-bzacH ligands. Bathochromic shift of the $\pi_{3}-\pi_{4} *$ were observed in Cl-bzacH and $\mathrm{NO}_{2}$-bzacH as compared to bzacH in chloroform. $\pi_{3}-\pi_{4}{ }^{*}$ Hypsochromic shifts of varying magnitude were observed in the $\mathrm{Ni}(\mathrm{Cl}-\mathrm{bzac})_{2} \cdot 2 \mathrm{H}_{2} \mathrm{O}$ and $\mathrm{Ni}\left(\mathrm{NO}_{2}-\mathrm{bzac}\right)_{2} \cdot 2 \mathrm{H}_{2} \mathrm{O}$ complexes in chloroform and methanol. Upon adduct formation, $\pi_{3}-\pi_{4} *$ Hypsochromic shifts were observed in all the adducts in chloroform except $\left[\mathrm{Ni}\left(\mathrm{Cl}\right.\right.$-bzac)(bipy) $\left.\left(\mathrm{H}_{2} \mathrm{O}\right)_{2}\right](\mathrm{Cl}$-bzac) which had bathochromic shift.The ligand field spectra band of $\mathrm{Ni}(\mathrm{Cl} \text {-bzac })_{2} \cdot 2 \mathrm{H}_{2} \mathrm{O}$ and $\mathrm{Ni}\left(\mathrm{NO}_{2} \text {-bzac }\right)_{2} \cdot 2 \mathrm{H}_{2} \mathrm{O}$ were typically of an octahedral geometry (Lever, 1986) while the shift observed in $\mathrm{Cu}(\mathrm{Cl} \text {-bzac })_{2}$ and $\mathrm{Cu}\left(\mathrm{NO}_{2} \text {-bzac }\right)_{2}$ suggest a four coordinate square planar geometry. Lower frequency shifts were observed in $\mathrm{Cu}(\mathrm{Cl} \text {-bzac })_{2}$ and $\mathrm{Cu}\left(\mathrm{NO}_{2} \text {-bzac }\right)_{2}$ in methanol relative to chloroform $\left[18,031 \mathrm{~cm}^{-1}\right.$ in chloroform $\rightarrow 15,625 \mathrm{~cm}^{-1}$ in methanol for $\left.\mathrm{Cu}(\mathrm{Cl} \text {-bzac })_{2}\right]$ and $\left[18,349 \mathrm{~cm}^{-1}\right.$ in chloroform $\rightarrow 15,198 \mathrm{~cm}^{-1}$ in methanol for $\mathrm{Cu}\left(\mathrm{NO}_{2} \text {-bzac }\right)_{2}$ ] which is an indication that the complexes are square planar in structure. Nickel(II) species have a large number of stereochemical forms in which the ion occurs, hence equilibrium between these forms are usually set up which are generally temperature, solvent and sometimes concentration dependent (Bailar et al, 1973). In solution, $\mathrm{Ni}(\mathrm{II}) \beta$-diketonates sometimes exhibit a monomer $\leftrightarrow$ trimer, square planar $\leftrightarrow$ octahedral equilibrium (Cotton and Wilkinson, 1980). Three transitions are expected for an octahedral nickel(II) ion in the region 7,000-13,000, $\mathrm{cm}^{-1}, 11,000-20,000 \mathrm{~cm}^{-1}, 19,000-27,000 \mathrm{~cm}^{-1}$ which are assigned to the ${ }^{3} \mathrm{~A}_{2 \mathrm{~g}}(\mathrm{~F}) \rightarrow{ }^{3} \mathrm{~T}_{2 \mathrm{~g}}(\mathrm{~F}),{ }^{3} \mathrm{~A}_{2 \mathrm{~g}}(\mathrm{~F}) \rightarrow{ }^{3} \mathrm{~T}_{1 \mathrm{~g}}(\mathrm{~F})$, ${ }^{3} \mathrm{~A}_{2 \mathrm{~g}}(\mathrm{~F}) \rightarrow{ }^{3} \mathrm{~T}_{1 \mathrm{~g}}(\mathrm{P})$ respectively. In the synthesized nickel(II) adducts, bands in the $11,442-12,821 \mathrm{~cm}^{-1}$ and $13,908-19,455 \mathrm{~cm}^{-1}$ region have been assigned to ${ }^{3} \mathrm{~A}_{2 \mathrm{~g}}(\mathrm{~F}) \rightarrow{ }^{3} \mathrm{~T}_{2 \mathrm{~g}}(\mathrm{~F}),{ }^{3} \mathrm{~A}_{2 \mathrm{~g}}(\mathrm{~F}) \rightarrow{ }^{3} \mathrm{~T}_{1 \mathrm{~g}}(\mathrm{~F})$ transitions respectively(Lever, 1986; Osowole et al, 2000). The visible spectra of the synthesized copper(II) adducts had a single band between $14,006-15,625 \mathrm{~cm}^{-1}$ which is consistent with the adoption of square pyramidal geometry for copper(II) compounds (Odunola et al, 2003). In addition, higher frequency shifts were observed in the ligand field spectral of the copper(II) adducts in methanol as compared with chloroform. $\left[\mathrm{Cu}(\mathrm{Cl}-\mathrm{bzac})(\mathrm{bipy})\left(\mathrm{H}_{2} \mathrm{O}\right)\right](\mathrm{Cl}-\mathrm{bzac})$ had a band in the $14,205 \mathrm{~cm}^{-1}$ region in chlorofom and this band was shifted to $16,393 \mathrm{~cm}^{-1}$ in methanol. This is an indication that the compound is a five coordinate square pyramidal geometry (Patel and Woods, 1990a). The electronic reflectance spectra of the ligands, complexes and adducts in the ultraviolet region exhibited single peak between 31,056-37,453 $\mathrm{cm}^{-1}$ with an additional peak observed between 39,683-48,544 $\mathrm{cm}^{-1}$ which have been assigned to $\pi_{3}-\pi_{4} *$ and charge transfer (CT) respectively. The visible region of the spectra showed that the nickel(II) compounds were octahedral in geometry while the copper(II) complexes and adducts were square planar and square pyramidal in geometry respectively.

\section{Conclusion}

Probable six coordinate octahedral geometry is suggested for all the nickel(II) compounds while a probable five coordinate, square pyramidal geometry is suggested for the copper(II) compounds except $\mathrm{Cu}(\mathrm{Cl}-\mathrm{bzac})_{2}$ and $\mathrm{Cu}\left(\mathrm{NO}_{2} \text {-bzac }\right)_{2}$ which are square planar in structure.

\section{References}

Bailar, J.C. Jr, Emeleus, H.J., Nyholm, R. and Trotman-Dickenson, A.F. (1973). Comprehensive inorganic chemistry. Pergamon: Oxford. pp 1139-1159.

Belford, R.L., Martell, A.E. and Calvin, M. (1956). Influence of fluorine substitution on the properties of metal chelate compounds- I. copper (II) chelates of bidentate ligands. Journal of Inorganic Nuclear Chemistry, 2, 11-31.

Collman, J.P., Marshall, R.L., Young, W.L., and Goldby, S. (1962). Reactions of metal chelates. Nitration and formylation of metal acetylacetonates. Inorganic Chemistry, 1(3), 704-710.

Cotton, F.A. and Wilkinson, G. (1980). Advanced inorganic chemistry. $4^{\text {th }}$ ed. New York: Wiley and sons Inc. pp 627-628, 783-821.

Cotton, F.A. and Wilkinson, G. (1988). Advanced Inorganic Chemistry. $5^{\text {th }}$ ed. Canada: John Wiley \& Sons, Inc. 768.

Ebeid, F.M., Rihan T.I. and Hassanein, M. (1966). A simple method for preparation of metal acetylacetonates and their nitro derivatives. Indian Journal of Chemistry, 4, 451-452. 
Holtzclaw, H.F. Jr. and Collman, J.P. (1957). Infrared absorption of metal chelate compounds of 1,3-diketones. Journal of American Chemical Society, 79, 3318-3322.

Koshimura, H., Saito, J. and Okubo, T. (1973). Effect of substituents on the keto-enol equilibrium of alkyl substituted $\beta$-diketones. Bulletin of the Chemical Society of Japan, 46, 632-634.

Laintd, K. E., Wai, C. M., Yonker, C. R., and Smith, R. D. (1992). Extraction of Metal Ions from Liquid and Solid Materials by Supercritical Carbon Dioxide. Anal. Chem., 64, 2875-2878.

Lalntz, K.E., and Tachlkawa, E. (1994). Extraction of Lanthanides from acidic solution using tributyl phosphate modified supercritical carbon dioxide. Anal. Chem., 66, 2190-2193.

Lever A.B.P. (1986). Inorganic Electronic Spectroscopy, 4th Ed.; Elsevier: London, 481-579.

Nakamoto, K., McCarthy, P.J. Ruby, A. and Martell, A.E. (1961). Infrared spectra of metal chelate compounds. II. Infrared spectra of acetylacetonates of trivalent metals. Journal of American Chemical Society, 83, 1066-1069.

Odunola, O.A., Oladipo, M.A., Woods, J.A.O., and Gelebe, A.C. (2003). Synthesis and structural studies of some ternary copper(II) complexes containing $\beta$-diketones with 1,10-phenanthroline and 2,2'-bipyridyl and $\mathrm{x}$-ray structure of $\left[\mathrm{Cu}\left(\mathrm{C}_{6} \mathrm{H}_{5} \mathrm{COCHCOCH}_{3}\right)(\right.$ bipy)Cl]. Synthesis and Reactivity in Inorganic and Metal-Organic Chemistry, 33(5), 857-871.

Onawumi, O.O.E., Faboya, O.O.P., Odunola, O.A., Prasad, T.K., Rajesekharan, M.V. (2008). Synthesis, structure and spectral studies on mixed ligand copper(II) complexes of diimines and acetylacetonate. Polyhedron, 27, 113-117.

Osowole, A.A., Woods, J.A.O. and Odunola, O.A. (2000). Synthesis and characterization of some Nickel(II) $\beta$-ketoamines and their adducts with 2,2'-bipyridine and 1,10-phenanthroline. Synthesis and Reactivity in Inorganic and Metal-Organic Chemistry, 32(4), 783-799.

Patel, K.S. and Woods J.A.O. (1990a). Preparation and physico-chemical studies of some 3-substituted-2,4-pentanedionato copper(II) complexes and their adducts. Synthesis and Reactivity of Inorganic and Metal Organic Chemistry, 20(1), 97-109.

Patel, K.S. and Woods J.A.O. (1990b). Synthesis and properties of nickel(II) complexes of various 3-alkyl-2,4-pentanediones and their adducts with 2,2'-bipyridine and 1,10-phenanthroline. Synthesis and Reactivity of Inorganic and Metal Organic Chemistry, 20(4), 409-424.

Patel, K.S. and Woods J.A.O. (1990c). Synthesis and physico-chemical properties of Bis(3-akyl-2,4-pentanedionato) copper(II) complexes and their adducts with 2,2'-bipyridine and 1,10-phenanthroline. Synthesis and Reactivity of Inorganic and Metal Organic Chemistry, 20(7), 909-922.

Singh, P.R. and Sahai, R. (1967a). Chemical and spectroscopic studies in metal $\beta$-diketonates. I. Preparation and study of halogenated metal acetylacetonates. Australian Journal of Chemistry, 20, 639-648.

Singh, P.R. and Sahai, R. (1967b). Chemical and spectroscopic studies in metal $\beta$-diketonates. II. Nitration of metal $\beta$-diketonates. Australian Journal of Chemistry, 20, 649-655.

Tanaka, M., Shono,T. and Shinra, K. (1969). Tautomerism in 3-substituted 2,4-pentanediones and their copper chelates. Bulletin of the Chemical Society of Japan, 42, 3190-3194.

Wang, J., Marshall, W. D. (1994). Recovery of Metals from Aqueous Media by Extraction with Supercritical Carbon Dioxide. Anal. Chem., 66, 1658-1663.

Wang, S., Eishani, S., Wai, C.M. (1995). Selective extraction of mercury with ionizable crown ethers in supercritical carbon dioxide. Anal. Chem., 67, 919-923.

Wenzel, T.J., Williams, E.J., Haltiwanger, R.C. and Sievers, R.E. (1985). Studies of metal chelates with the novel ligand 2,2,7-trimethyl-3,5-octanedione. Polyhedron, 4(3), 369-378.

Woods, J.A.O, Omoregie, H.O., Retta, N., Chebude, Y., Capittelli, F. (2009a). Synthesis and physicochemical studies of Nickel(II) complexes of 2-substituted-1,3-diphenyl-1,3-propanedione, their 2,2'-bipyridine and 1,10-phenanthroline adducts and X-ray structure of (2,2'-bipyridine)bis(1,3-diphenyl-1,3-propanedionato) Nickel(II). Synthesis and Reactivity in Inorganic, Metal-Organic, and Nano-Metal Chemistry, 39, 694-703.

Woods, J.A.O, Omoregie, H.O., Retta, N., Chebude, Y., Capittelli, F. (2009b). Synthesis and characterization of some Nickel(II) and Copper(II) complexes of 2-substituted-4,4,4-trifluoro-(2-thienyl)butane-1,3-dione (TTAH), their 2,2'-bipyridine and 1,10-phenanthroline adducts and X-ray structure of 
(2,2'-bipyridine)bis(4,4,4-trifluoro-(2-thienyl)butane-1,3-dionato) Nickel(II). Synthesis and Reactivity in Inorganic, Metal-Organic, and Nano-Metal Chemistry, 39, 704-717.

Woods, J.A.O. and Patel, K.S. (1994). Nickel(II) complexes of some 3-substituted-2,4-pentanediones and their adducts with 2,2'-bipyridine and 1,10-phenanthroline. Synthesis and Reactivity of Inorganic and Metal Organic Chemistry, 24(9), 1557-1571.

Table 1. Analytical and physical data of nickel(II) and copper(II) complexes of 2-substituted-1-phenyl-1,3-butanedione and their adducts

\begin{tabular}{|c|c|c|c|c|c|}
\hline Formula & M.Wt & Colour & $\begin{array}{l}\text { M.P. } \\
\left({ }^{\circ} \mathrm{C}\right)\end{array}$ & $\begin{array}{c}\text { Yield } \\
(\%)\end{array}$ & $\begin{array}{l}\mu_{\text {eff }} \\
\text { (B.M. }\end{array}$ \\
\hline $\mathrm{Ni}(\mathrm{Cl}-\mathrm{bzac})_{2} \cdot 2 \mathrm{H}_{2} \mathrm{O}$ & 486.09 & Green & $128-130$ & 51.58 & 2.90 \\
\hline$\left[\mathrm{Ni}(\mathrm{Cl}\right.$-bzac $)($ bipy $\left.)\left(\mathrm{H}_{2} \mathrm{O}\right)_{2}\right](\mathrm{Cl}$-bzac $)$ & 642.28 & Pink & $124-126$ & 61.86 & 2.93 \\
\hline$\left[\mathrm{Ni}(\text { phen })_{3}\left(\mathrm{H}_{2} \mathrm{O}\right)_{2}\right](\mathrm{Cl}-\mathrm{bzac})_{2}$ & 1026.71 & Pink & $138-140$ & 40.36 & 3.28 \\
\hline$\left[\mathrm{Ni}(\text { phen })_{2}\left(\mathrm{H}_{2} \mathrm{O}\right)_{2}\right](\mathrm{Cl} \text {-bzac })_{2}$ & 846.49 & Pink & $198-200$ & 82.67 & 3.08 \\
\hline $\mathrm{Ni}\left(\mathrm{NO}_{2}-\mathrm{bzac}\right)_{2} \cdot 2 \mathrm{H}_{2} \mathrm{O}$ & 507.10 & L.Green & 168 & 52.32 & 2.96 \\
\hline $\mathrm{Ni}\left(\mathrm{NO}_{2} \text {-bzac }\right)_{2}$.bipy & 627.25 & Green & $218-219$ & 77.78 & 3.02 \\
\hline$\left[\mathrm{Ni}\left(\mathrm{NO}_{2}\right.\right.$-bzac $\left.)(\text { phen })_{2}\right]\left(\mathrm{NO}_{2}\right.$-bzac $)$ & 831.47 & L.Brown & 196-198 & 69.42 & 3.18 \\
\hline $\mathrm{Cu}(\mathrm{Cl}-\mathrm{bzac})_{2}$ & 454.84 & Green & $220-222$ & 61.34 & 1.79 \\
\hline$\left[\mathrm{Cu}(\mathrm{Cl}\right.$-bzac $)($ bipy $\left.)\left(\mathrm{H}_{2} \mathrm{O}\right)\right](\mathrm{Cl}$-bzac $)$ & 629.05 & D.Green & $175-177$ & 89.13 & 2.19 \\
\hline $\mathrm{Cu}(\mathrm{Cl}$-bzac $)$ phen $\left.)\left(\mathrm{H}_{2} \mathrm{O}\right)\right](\mathrm{Cl}$-bzac $)$ & 653.06 & D.Green & 207-209 & 34.82 & 1.98 \\
\hline $\mathrm{Cu}\left(\mathrm{NO}_{2} \text {-bzac }\right)_{2}$ & 475.85 & Green & $145-147$ & 89.13 & 1.44 \\
\hline$\left[\mathrm{Cu}\left(\mathrm{NO}_{2}\right.\right.$-bzac $)($ bipy $\left.)\left(\mathrm{H}_{2} \mathrm{O}\right)\right]$ & 650.06 & Green & $170-172$ & 56.03 & 1.73 \\
\hline $\mathrm{Cu}\left(\mathrm{NO}_{2} \text {-bzac }\right)_{2}$.phen & 656.05 & Green & $185-187$ & 25.67 & 2.01 \\
\hline
\end{tabular}

$\mathrm{D}=$ dark, $\mathrm{L}=$ light

Table 2. Microanalytical data of nickel(II) and copper(II) complexes of 2-substituted-1-phenyl-1,3-butanedione and their adducts

\begin{tabular}{|c|c|c|c|c|c|c|c|c|}
\hline \multirow[t]{2}{*}{ Emperical formula } & \multicolumn{4}{|c|}{$\%$ Found } & \multicolumn{4}{|c|}{$\%$ Calculated } \\
\hline & $\mathrm{C}$ & $\mathrm{H}$ & $\mathrm{N}$ & Metal & $\mathrm{C}$ & $\mathrm{H}$ & $\mathrm{N}$ & Metal \\
\hline $\mathrm{Ni}(\mathrm{Cl}-\mathrm{bzac})_{2} \cdot 2 \mathrm{H}_{2} \mathrm{O}$ & 50.17 & 4.10 & - & 11.78 & 49.41 & 4.16 & - & 12.08 \\
\hline$\left[\mathrm{Ni}(\mathrm{Cl}\right.$-bzac $)($ bipy $\left.)\left(\mathrm{H}_{2} \mathrm{O}\right)_{2}\right](\mathrm{Cl}$-bzac $)$ & 55.70 & 4.55 & 4.02 & 9.42 & 56.10 & 4.40 & 4.36 & 9.42 \\
\hline$\left[\mathrm{Ni}(\text { phen })_{3}\left(\mathrm{H}_{2} \mathrm{O}\right)_{2}\right](\mathrm{Cl}-\mathrm{bzac})_{2}$ & 65.69 & 4.03 & 7.83 & 6.22 & 65.51 & 4.33 & 8.18 & 5.72 \\
\hline$\left[\mathrm{Ni}(\text { phen })_{2}\left(\mathrm{H}_{2} \mathrm{O}\right)_{2}\right](\mathrm{Cl} \text {-bzac })_{2}$ & 62.04 & 3.98 & 7.02 & 6.80 & 62.43 & 4.30 & 6.62 & 6.85 \\
\hline $\mathrm{Ni}\left(\mathrm{NO}_{2}-\mathrm{bzac}\right)_{2} \cdot 2 \mathrm{H}_{2} \mathrm{O}$ & 46.97 & 4.28 & 5.82 & 11.33 & 47.37 & 3.98 & 5.52 & 11.58 \\
\hline $\mathrm{Ni}\left(\mathrm{NO}_{2} \text {-bzac }\right)_{2}$.bipy & 56.94 & 4.05 & 9.12 & 9.11 & 57.44 & 3.86 & 8.92 & 9.34 \\
\hline$\left[\mathrm{Ni}\left(\mathrm{NO}_{2}\right.\right.$-bzac $\left.)(\text { phen })_{2}\right]\left(\mathrm{NO}_{2}\right.$-bzac $)$ & 64.01 & 4.32 & 9.82 & 7.50 & 63.55 & 3.89 & 10.10 & 7.06 \\
\hline $\mathrm{Cu}(\mathrm{Cl} \text {-bzac })_{2}$ & 52.24 & 3.84 & - & 13.7 & 52.81 & 3.55 & - & 13.96 \\
\hline$\left[\mathrm{Cu}(\mathrm{Cl}\right.$-bzac $)($ bipy $\left.)\left(\mathrm{H}_{2} \mathrm{O}\right)\right](\mathrm{Cl}$-bzac $)$ & 56.83 & 4.07 & 4.15 & 10.19 & 57.28 & 4.17 & 4.45 & 10.09 \\
\hline$[\mathrm{Cu}(\mathrm{Cl}$-bzac $)$ phen $\left.)\left(\mathrm{H}_{2} \mathrm{O}\right)\right](\mathrm{Cl}$-bzac $)$ & 59.09 & 3.77 & 4.79 & 9.40 & 58.85 & 4.02 & 4.29 & 9.72 \\
\hline $\mathrm{Cu}\left(\mathrm{NO}_{2} \text {-bzac }\right)_{2}$ & 50.18 & 3.20 & 5.82 & 13.33 & 50.48 & 3.40 & 5.88 & 13.34 \\
\hline$\left[\mathrm{Cu}\left(\mathrm{NO}_{2}\right.\right.$-bzac $)($ bipy $\left.)\left(\mathrm{H}_{2} \mathrm{O}\right)\right]$ & 55.81 & 3.92 & 9.01 & 9.47 & 55.43 & 4.04 & 8.61 & 9.77 \\
\hline $\mathrm{Cu}\left(\mathrm{NO}_{2} \text {-bzac }\right)_{2}$.phen & 5858.58 & 3.69 & 8.54 & 9.68 & 58.50 & 3.86 & 8.63 & 9.62 \\
\hline
\end{tabular}


Table 3. Relevant Infrared Spectra bands (cm- $\left.{ }^{1}\right)$ of nickel(II) and copper(II) complexes of 2-substituted-1-phenyl-1,3-butanedione and their adducts

\begin{tabular}{|c|c|c|c|c|c|}
\hline Formula & $\mathrm{C}=\mathrm{O}, \mathrm{C}=\mathrm{C}$ & $v_{\mathrm{s}}(\mathrm{C}-\mathrm{O})+\delta \mathrm{C}-\mathrm{H}$ & $\delta_{\mathrm{as}}\left(\mathrm{CH}_{3}\right)+\delta_{\mathrm{s}}\left(\mathrm{CH}_{3}\right)$ & \multicolumn{2}{|c|}{$\delta(\mathrm{C}-\mathrm{H}) \mathrm{Phen} / \mathrm{bipy}$} \\
\hline bzacH & $1599 \mathrm{~m}, 1540 \mathrm{~b}$ & $1484 \mathrm{~m}$ & \multicolumn{2}{|l|}{$1413 \mathrm{~m}, 1360 \mathrm{~m}$} & - \\
\hline Cl-bzacH & $1749 \mathrm{w} 1724 \mathrm{w} 1686 \mathrm{~m}$ & $1449 w$ & $1359 w$ & & \\
\hline $\mathrm{Ni}(\mathrm{Cl}-\mathrm{bzac})_{2} \cdot 2 \mathrm{H}_{2} \mathrm{O}$ & $1689 w 1591 \mathrm{~s} 1563 \mathrm{~s}$ & $1487 \mathrm{~m} 1448 \mathrm{w}$ & v $1352 \mathrm{w}$ & & \\
\hline$\left[\mathrm{Ni}(\mathrm{Cl}-\mathrm{bzac})(\right.$ bipy $\left.)\left(\mathrm{H}_{2} \mathrm{O}\right)_{2}\right](\mathrm{Cl}$-bzac $)$ & $1598 \mathrm{~s} 1570 \mathrm{~m} 1509 \mathrm{~m}$ & $1443 m$ & $1406 \mathrm{~m}$ & \multicolumn{2}{|c|}{$768 \mathrm{~s}$} \\
\hline$\left[\mathrm{Ni}(\text { phen })_{3}\left(\mathrm{H}_{2} \mathrm{O}\right)_{2}\right](\mathrm{Cl}-\mathrm{bzac})_{2}$ & $1626 \mathrm{~m} 1587 \mathrm{~m} \mathrm{1516s}$ & $1462 w$ & $1424 \mathrm{~s}$ & \multirow{2}{*}{$\begin{array}{l}847 \mathrm{~s} \\
851 \mathrm{~s}\end{array}$} & $726 \mathrm{~s}$ \\
\hline$\left[\mathrm{Ni}(\text { phen })_{2}\left(\mathrm{H}_{2} \mathrm{O}\right)_{2}\right](\mathrm{Cl} \text {-bzac })_{2}$ & $1736 \mathrm{~b} 1627 \mathrm{w} 1594 \mathrm{~s}$ & $1457 \mathrm{~s}$ & $1399 \mathrm{~s}$ & & $727 \mathrm{~s}$ \\
\hline $\mathrm{NO}_{2}$-bzacH & $1600 \mathrm{~m} 1567 \mathrm{w}$ & $1462 \mathrm{~m}$ & \multicolumn{2}{|l|}{$1412 w 1360 \mathrm{~m}$} & \\
\hline $\mathrm{Ni}\left(\mathrm{NO}_{2} \text {-bzac }\right)_{2} \cdot 2 \mathrm{H}_{2} \mathrm{O}$ & $1592 \mathrm{~s} 1561 \mathrm{~s} 1516 \mathrm{~s}$ & $1484 \mathrm{~m} \mathrm{1452s}$ & \multicolumn{2}{|l|}{$1403 \mathrm{~m}$} & \\
\hline $\mathrm{Ni}\left(\mathrm{NO}_{2} \text {-bzac }\right)_{2}$.bipy & 1595 vs $1570 v s$ s $1506 v s$ & $1484 \mathrm{vs} 1456 \mathrm{~s}$ & $1358 w$ & \multicolumn{2}{|c|}{$772 v s$} \\
\hline$\left[\mathrm{Ni}\left(\mathrm{NO}_{2}\right.\right.$-bzac $\left.)(\text { phen })_{2}\right]\left(\mathrm{NO}_{2}\right.$-bzac $)$ & $1624 \mathrm{w} 1593 \mathrm{~s} 1564 \mathrm{~s}$ & $1484 \mathrm{~m} 1457 \mathrm{~m}$ & n $1399 \mathrm{~s}$ & \multirow[t]{2}{*}{$851 \mathrm{~s}$} & \multirow[t]{2}{*}{$727 \mathrm{~s}$} \\
\hline $\mathrm{Cu}(\mathrm{Cl}-\mathrm{bzac})_{2}$ & $1553 \mathrm{~s} 1516 \mathrm{~m}$ & $1487 \mathrm{w} 1443 \mathrm{~m}$ & n $1395 \mathrm{~m}$ & & \\
\hline$\left[\mathrm{Cu}(\mathrm{Cl}\right.$-bzac $)($ bipy $\left.)\left(\mathrm{H}_{2} \mathrm{O}\right)\right](\mathrm{Cl}$-bzac $)$ & $1592 \mathrm{~s} 1589 \mathrm{~m} 1521 \mathrm{~s}$ & $1490 \mathrm{~m} \mathrm{1448s}$ & $1385 \mathrm{~s}$ & \multicolumn{2}{|c|}{$764 \mathrm{~s}$} \\
\hline$[\mathrm{Cu}(\mathrm{Cl}-\mathrm{bzac})$ (phen $\left.)\left(\mathrm{H}_{2} \mathrm{O}\right)\right](\mathrm{Cl}-\mathrm{bzac})$ & $1597 \mathrm{~m} 1564 \mathrm{~m} \mathrm{1518s}$ & $1486 \mathrm{~m} 1450 \mathrm{~m}$ & n $1388 \mathrm{~s}$ & \multirow[t]{2}{*}{$852 \mathrm{~s}$} & \multirow[t]{2}{*}{$724 \mathrm{~s}$} \\
\hline $\mathrm{Cu}\left(\mathrm{NO}_{2} \text {-bzac }\right)_{2}$ & $1587 \mathrm{~m} 1565 \mathrm{~s} 1523 \mathrm{~s}$ & $1488 \mathrm{~m} 1453 \mathrm{~m}$ & n $1401 \mathrm{~s} \quad 1360 \mathrm{~m}$ & & \\
\hline$[\mathrm{Cu}(\mathrm{Cl}-\mathrm{bzac})$ (phen $\left.)\left(\mathrm{H}_{2} \mathrm{O}\right)\right](\mathrm{Cl}-\mathrm{bzac})$ & $1666 \mathrm{~s} 1589 \mathrm{~s} 1561 \mathrm{~s}$ & $1488 \mathrm{~s} 1451 \mathrm{~m}$ & $1390 \mathrm{~s}$ & \multicolumn{2}{|c|}{$774 \mathrm{~s}$} \\
\hline $\mathrm{Cu}\left(\mathrm{NO}_{2} \text {-bzac }\right)_{2}$.phen & 1716w 1595s 1568s & $1486 \mathrm{~m} 1450 \mathrm{~m}$ & n $1387 \mathrm{~s}$ & $852 \mathrm{~s}$ & $724 \mathrm{~s}$ \\
\hline
\end{tabular}


Table 4. The electronic solution spectra of nickel(II) and copper(II) complexes of 2-substituted-1-phenyl-1,3-butanedione and their adducts

\begin{tabular}{|c|c|c|c|c|}
\hline \multirow[t]{2}{*}{ Emperical Formula } & \multicolumn{2}{|c|}{$\pi_{3} \pi_{4} *\left(\mathrm{~cm}^{-1}\right)$} & \multicolumn{2}{|l|}{$d-d$} \\
\hline & $\mathrm{CHCl}_{3}$ & $\mathrm{CH}_{3} \mathrm{OH}$ & $\mathrm{CHCl}_{3}$ & $\mathrm{CH}_{3} \mathrm{OH}$ \\
\hline bzacH & $32,258(7247)$ & $32,258(18259)$ & - & - \\
\hline Cl-bzacH & $31,250 *$ & $32,051(?)$ & - & - \\
\hline $\mathrm{Ni}(\mathrm{Cl}-\mathrm{bzac})_{2} \cdot 2 \mathrm{H}_{2} \mathrm{O}$ & $33,333^{*}$ & $34,247^{*}$ & $\begin{array}{l}17,422(67) \\
13,850(59)\end{array}$ & $15,974(16)$ \\
\hline$\left[\mathrm{Ni}(\mathrm{Cl}\right.$-bzac $)($ bipy $\left.)\left(\mathrm{H}_{2} \mathrm{O}\right)_{2}\right](\mathrm{Cl}$-bzac $)$ & $33,113(?)$ & $\begin{array}{l}33,784(29412) \\
12,690(?)\end{array}$ & $\begin{array}{l}17,730(?) \\
12,755(41)\end{array}$ & $17,544(60)$ \\
\hline$\left[\mathrm{Ni}(\text { phen })_{3}\left(\mathrm{H}_{2} \mathrm{O}\right)_{2}\right](\mathrm{Cl} \text {-bzac })_{2}$ & $34,014(?)$ & $34,014(18085)$ & $\begin{array}{l}19,048(?) \\
13,908(?)\end{array}$ & $\begin{array}{l}19,455(56) \\
12,755(8) \\
11,442(8)\end{array}$ \\
\hline$\left[\mathrm{Ni}(\text { phen })_{2}\left(\mathrm{H}_{2} \mathrm{O}\right)_{2}\right](\mathrm{Cl} \text {-bzac })_{2}$ & $34,247(31759)$ & $34,247(26188)$ & $\begin{array}{l}17,857(89) \\
12,853(73)\end{array}$ & $\begin{array}{l}18,450(24) \\
12,563(8)\end{array}$ \\
\hline $\mathrm{NO}_{2}$-bzacH & $32,154(27141)$ & $32,051(22717)$ & - & - \\
\hline $\mathrm{Ni}\left(\mathrm{NO}_{2}-\mathrm{bzac}\right)_{2} \cdot 2 \mathrm{H}_{2} \mathrm{O}$ & $34,014 *$ & $34,483 *$ & $15,723(15)$ & $\begin{array}{l}18,587(43) \\
12,821(15)\end{array}$ \\
\hline $\mathrm{Ni}\left(\mathrm{NO}_{2} \text {-bzac }\right)_{2}$.bipy & $34,420(29568)$ & $34,480(29765)$ & $\begin{array}{l}17,870(60) \\
12,600(55)\end{array}$ & $\begin{array}{l}17,560(68) \\
12,080(40)\end{array}$ \\
\hline$\left[\mathrm{Ni}\left(\mathrm{NO}_{2}\right.\right.$-bzac $\left.)(\text { phen })_{2}\right]\left(\mathrm{NO}_{2}\right.$-bzac $)$ & $34,247(30811)$ & $34,247(39952)$ & $\begin{array}{l}17,373(98) \\
12,987(72)\end{array}$ & $\begin{array}{l}18,587(43) \\
12,821(15)\end{array}$ \\
\hline $\mathrm{Cu}(\mathrm{Cl} \text {-bzac })_{2}$ & $32,468(12998)$ & $31,056(?)$ & $12,690(113)$ & $\begin{array}{l}15,625(?) \\
11,848(?)\end{array}$ \\
\hline$\left[\mathrm{Cu}(\mathrm{Cl}\right.$-bzac $)($ bipy $\left.)\left(\mathrm{H}_{2} \mathrm{O}\right)\right](\mathrm{Cl}$-bzac $)$ & $33,557(66659)$ & $33,333(53582)$ & $14,205(489)$ & $16,393(161)$ \\
\hline$[\mathrm{Cu}(\mathrm{Cl}$-bzac $)$ phen $\left.)\left(\mathrm{H}_{2} \mathrm{O}\right)\right](\mathrm{Cl}$-bzac $)$ & $34,014(?)$ & $34,014(44970)$ & $14,006(?)$ & $16,129(137)$ \\
\hline $\mathrm{Cu}\left(\mathrm{NO}_{2}-\mathrm{bzac}\right)_{2}$ & $31,447(36456)$ & $33,898 *$ & $\begin{array}{l}18,349 * \\
15,060(128)\end{array}$ & $15,198(70)$ \\
\hline$\left[\mathrm{Cu}\left(\mathrm{NO}_{2}\right.\right.$-bzac $)($ bipy $\left.)\left(\mathrm{H}_{2} \mathrm{O}\right)\right]$ & $32,258(58721)$ & $32,680(31224)$ & $15,625(82)$ & $16,447(96)$ \\
\hline $\mathrm{Cu}\left(\mathrm{NO}_{2} \text {-bzac }\right)_{2}$.phen & $34,014(31249)$ & $34,014(38037)$ & $14,164(224)$ & $16,287(185)$ \\
\hline
\end{tabular}

? Compounds partially soluble in the solvent.

*Shoulder 
Table 5. The electronic solid reflectance spectra of nickel(II) and copper(II) complexes of 2-substituted-1-phenyl-1,3-butanedione and their adducts

\begin{tabular}{|c|c|c|}
\hline Emperical Formula & $\pi_{3-} \pi_{4} *\left(\mathrm{~cm}^{-1}\right)$ & $d-d$ \\
\hline Cl-bzacH & 35,971 & - \\
\hline $\mathrm{Ni}(\mathrm{Cl}-\mathrm{bzac})_{2} \cdot 2 \mathrm{H}_{2} \mathrm{O}$ & 32,154 & $18,484,12,019$ \\
\hline$\left[\mathrm{Ni}(\mathrm{Cl}-\mathrm{bzac})(\mathrm{bipy})\left(\mathrm{H}_{2} \mathrm{O}\right)_{2}\right](\mathrm{Cl}-\mathrm{bzac})$ & 36,364 & $20,325,14,749,12,642$ \\
\hline$\left[\mathrm{Ni}(\text { phen })_{3}\left(\mathrm{H}_{2} \mathrm{O}\right)_{2}\right](\mathrm{Cl}-\mathrm{bzac})_{2}$ & 31,056 & $21,645,15,480,12,048$ \\
\hline$\left[\mathrm{Ni}(\text { phen })_{2}\left(\mathrm{H}_{2} \mathrm{O}\right)_{2}\right](\mathrm{Cl} \text {-bzac })_{2}$ & 31,348 & $20,790,14,749,12,739$ \\
\hline $\mathrm{NO}_{2}-\mathrm{bzacH}$ & 37,453 & - \\
\hline $\mathrm{Ni}\left(\mathrm{NO}_{2}-\mathrm{bzac}\right)_{2} \cdot 2 \mathrm{H}_{2} \mathrm{O}$ & 36,900 & $18,349,12,063$ \\
\hline $\mathrm{Ni}\left(\mathrm{NO}_{2} \text {-bzac }\right)_{2} \cdot$ bipy & 36,630 & $20,325,13,587,12,642$ \\
\hline$\left[\mathrm{Ni}\left(\mathrm{NO}_{2}\right.\right.$-bzac $\left.)(\text { phen })_{2}\right]\left(\mathrm{NO}_{2}\right.$-bzac $)$ & 31,157 & $19,802,14,306,12,500$ \\
\hline $\mathrm{Cu}(\mathrm{Cl}-\mathrm{bzac})_{2}$ & 34,364 & $20,000,17,007,12,121$ \\
\hline$\left[\mathrm{Cu}(\mathrm{Cl}-\mathrm{bzac})(\right.$ bipy $\left.)\left(\mathrm{H}_{2} \mathrm{O}\right)\right](\mathrm{Cl}-\mathrm{bzac})$ & 36,101 & 14,724 \\
\hline$\left[\mathrm{Cu}(\mathrm{Cl}-\mathrm{bzac})(\right.$ phen $\left.)\left(\mathrm{H}_{2} \mathrm{O}\right)\right](\mathrm{Cl}-\mathrm{bzac})$ & 34,247 & 14,305 \\
\hline $\mathrm{Cu}\left(\mathrm{NO}_{2}-\mathrm{bzac}\right)_{2}$ & 31,847 & $20,284,16,155,12,210$ \\
\hline$\left[\mathrm{Cu}\left(\mathrm{NO}_{2}-\mathrm{bzac}\right)(\right.$ bipy $\left.)\left(\mathrm{H}_{2} \mathrm{O}\right)\right]$ & 36,101 & 15,325 \\
\hline $\mathrm{Cu}\left(\mathrm{NO}_{2} \text {-bzac }\right)_{2}$.phen & 35,345 & 14,987 \\
\hline
\end{tabular}
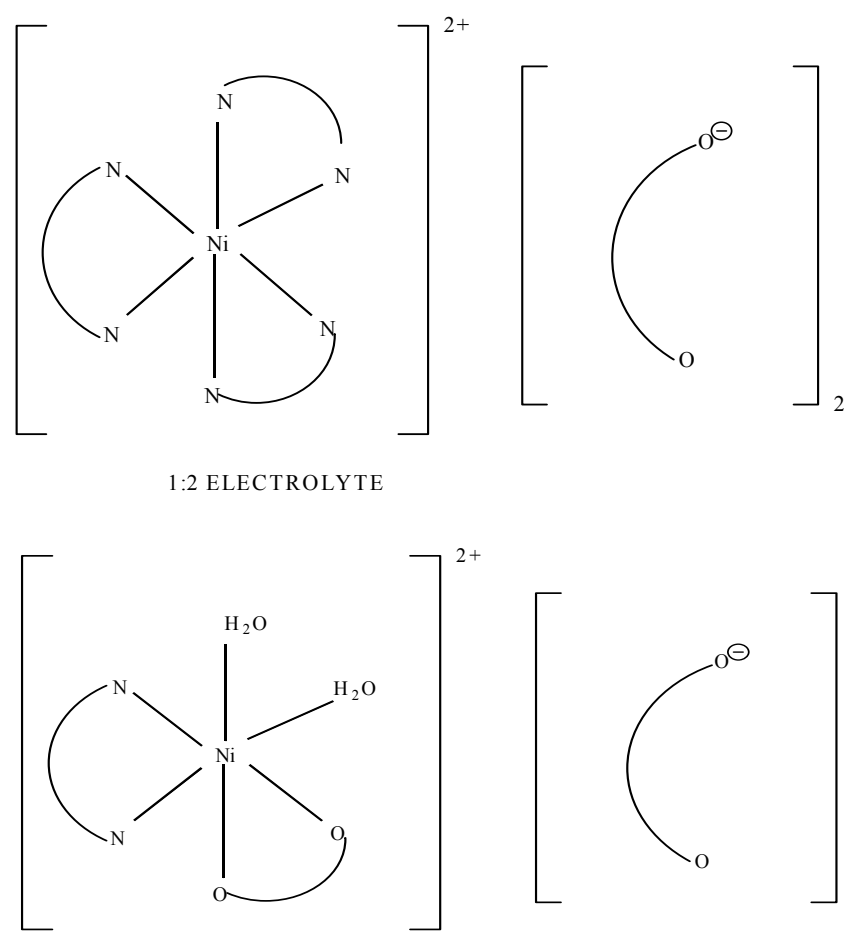

1:1 ELECTROLYTE 

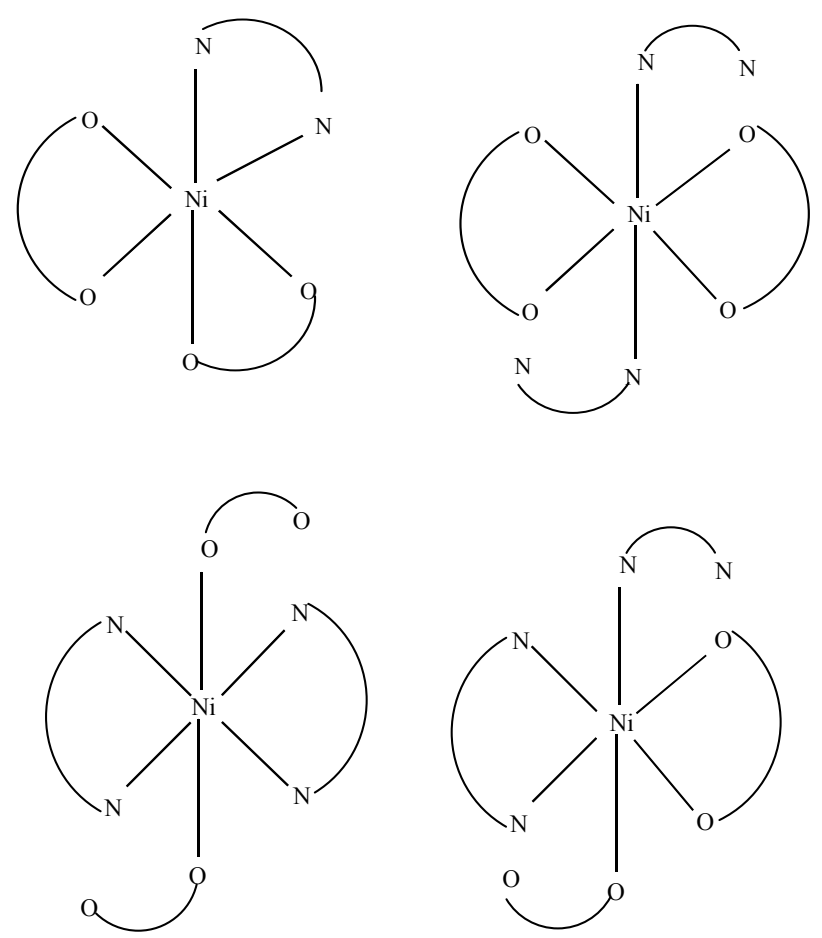

Figure 1. Proposed structures for Nickel adducts
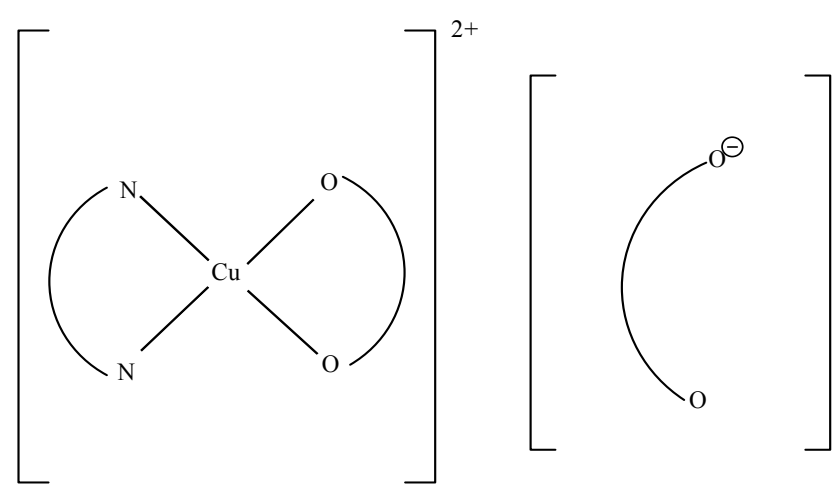

1:1 ELECTROLYTE
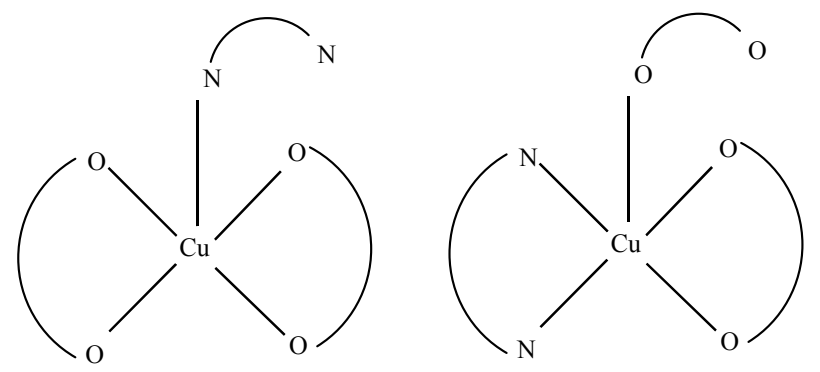

Figure 2. Proposed structures for Copper adducts 